MANAGEMENT FOR HAIRDRESSERS 


\title{
MANAGEMENT FOR HAIRDRESSERS
}

\author{
CAROL PARSONS
}

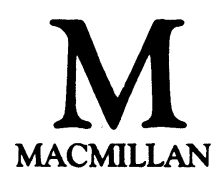




\section{(C) Carol Parsons 1985}

All rights reserved. No part of this publication may be reproduced or transmitted, in any form or by any means, without permission.

First published 1985 by

MACMILLAN EDUCATION LTD

Houndmills, Basingstoke, Hampshire RG21 2XS and London

Companies and representatives throughout the world 
To B.M.R. with thanks 


\section{Contents}

Preface

Introduction

1 In the beginning 1

The area, the location, other factors, other options, consulting the experts.

2 Being Self-employed

National Insurance, income tax.

3 Types of Business

Sole trader, partnerships, the registered company, types of company, limited liability, registering a company, the Memorandum, the Articles, disadvantages of the company.

4 Raising Finance

Money to start a salon, the clearing banks, security, what the bank manager will want to know, money to run the salon, overdrafts, bridging loans, longer loans, finance houses, other sources, hire purchase, credit sale, contract hire.

5 The Premises

Buying, renting, security of tenure, altering the premises, planning permission, building regulations, Offices, Shops and Railway Premises Act, fire regulations, salon layout, the colour scheme, materials, lighting.

6 Stock and Equipment

Stock and stock control, purchasing equipment.

7 Public Relations

Attracting clients, keeping clients. 
8 Employers and the Law

Wages, general information, enforcement, employment rights, the normal working week, continuous service, written particulars of employment, itemised pay statements, guarantee payments, maternity pay, notice to terminate employment, reasons for dismissal, unfair dismissal, fair dismissal, misconduct, gross misconduct, Industrial Tribunals, compensation, redundancy, short time and lay-off, redundancy payments, transfer of undertakings, Employers' Liability (Compulsory Insurance) Act, equal pay, disabled workers, racial discrimination, sex discrimination.

9 Public Responsibilities

Contracts, negligence, handling dangerous substances, consumer protection, the Shops Acts, Health and Safety at Work Act, First Aid Regulations 1981, Fire Precautions Act, Offices, Shops and Railway Premises Act, Public Liability Insurance.

10 Looking After Your Finances

Documentary evidence, accounting for income, accounting for purchases, accounting for wages, bank statements, final accounts, PAYE, VAT, costing and budgeting, prices, profit level.

11 Extra Salon Services

Retailing, extra salon services.

12 Being a Manager

Recruitment, selection, the interview, level of staffing, training, special training, communicating with staff, the manager's role.

Appendixes

1 Trade organisations

2 Useful addresses

3 Specimen contract statement and specimen lease

4 Apprenticeships 


\section{Preface}

I became aware of the need for this book whilst teaching business studies to hairdressing students at Rotherham College of Arts and Technology. I have attempted to design it around two City and Guilds examinations: the paper on Salon Organisation and the paper on Salon Management. The book has not been the product of my labour alone. There are a number of people to whom I am indebted: Janet Kavanagh, who read the text and made some very helpful suggestions; Stuart Williamson, who planted the original idea and encouraged me to carry it out; Alistair Fyfe Holmes, who helped me in the initial stages; the following people who have helped in various capacities - David Vernon - Lew Owen - Irene Ratcliffe - John, Avril and Rosamund at Rotherham - Mary Harris - the hairdressing students over the past five years - Peter Goodenough (to whom I owe a good deal) - and finally Sue Marples who typed the manuscript so beautifully and so quickly. Thank you to everyone and apologies to anyone I have forgotten.

It is customary in every book to admit personal responsibility for errors. In this case, unfortunately, there is no one else to blame!

Carol Parsons 


\section{Introduction}

For the past five years I have had the pleasure and privilege of teaching the hairdressing students at Rotherham College of Arts and Technology. Each year I am impressed by the number who wish to own their own salons.

This book is aimed at those students and also at existing salon owners who wish to know a little more about what they are doing. The book takes the readers from the initial steps of buying a salon, through to actually running it. Having looked at other books on the market, I have included chapters on employment law and on public responsibilities as these are areas which worry salon owners. The book must be regarded as an introduction and does not claim to be a comprehensive guide to running your salon. In any areas of doubt, you should seek expert legal advice. 